Article

\title{
The Upshot on Princess Merida in Disney/Pixar's Brave: Why the Tomboy Trajectory Is Off Target
}

\author{
Lauren Dundes \\ Department of Sociology, McDaniel College, Westminster, MD 21157, USA; ldundes@mcdaniel.edu
}

Received: 25 June 2020; Accepted: 14 August 2020; Published: 16 August 2020

\begin{abstract}
Princess Merida, the "tomboy" princess in Disney/Pixar's Brave, won praise for escaping the strictures of femininity and maternal demands for feminine propriety. In addition to her overt defiance of gender roles and demand for agency, Merida also enacts hegemonic masculinity by mocking her suitors during an archery contest in which she is the prize. The ridicule is the prelude to her dramatic, winning bullseye that feminizes the men, in a scene rich in symbolism about gender and power. In enacting the final phase of the tomboy paradigm, however, Merida reverses her trajectory as her rebellion against femininity ebbs. She then resolves conflict by displaying vulnerability rather than performing brave deeds. This marked shift to a more traditional gender role raises questions about her stature as a model of autonomy able to withstand the pressure to conform.
\end{abstract}

Keywords: Disney princess; gender stereotypes; hegemonic masculinity; gender roles; archery; bullseye; humor; tomboy; emasculation

\section{Introduction}

The influence of Disney productions in socializing children has prompted significant discourse about what their content teaches young viewers (Giroux 1999; Zipes 2015), especially with the advent of the Disney Plus network. From its release in November 2019 until April 2020, Disney Plus attracted subscriptions in excess of 50 million (Swartz 2020). The corporate juggernaut's expanding dominance has resulted in calls to examine the values promulgated in its programming, with the perpetuation of gender stereotypes among the chief concerns (Dundes et al. 2018, 2019; England et al. 2011; Streiff and Dundes 2017a; Towbin et al. 2004) even as some scholars are sanguine about progress in Disney's portrayal of women's agency (Hine et al. 2018b; Leader 2018).

Princess Merida, the heroine of the 2012 Disney/Pixar film Brave, received notice for acting as her own narrator (unlike her same-era peer Rapunzel in Tangled), while asserting agency in resolving conflict (Whelan 2012). This desire to control her own fate occurred as she navigated the complexities of mother-daughter dynamics (Kapurch 2016; Manwell 2016), a long-standing cross-cultural theme in fairy tales and other children's stories (Tatar 2020). Within its depiction of mother-daughter tension, Disney/Pixar explored a "range of femininities" in which Merida as "mighty maiden" breaks free of the princess mold (Reilly 2016, p. 58). Even with its coverage of the fraught balance between "masculine" and "feminine" traits in a role model for children, Disney/Pixar won significant acclaim for Brave (Pixar.com 2020; see the lengthy "Awards" section on Pixar website). In fact, folklorist Jack Zipes lauded Brave as "a feminist fairy-tale film" with an empowering departure from the tale of "King Thrushbeard", a story with a tale type that closely aligns with the plot of Brave (Aarne-Thompson tale type 900) (Zipes 2015).

Zipes notes Brave's significant twist on this tale type that usually depicts the comeuppance of an arrogant princess that rejects and deprecates her suitors. In contrast, Merida's derision and emasculation of her suitors incurs her mother's wrath, but only in the short term. Nevertheless, despite the fact that Merida fares better than other maidens in stories encompassed by this tale type, it is 
arguable whether her "tomboy" rebellion frees her from constraints imposed by traditional femininity. Centered around a plot in which she escapes an arranged marriage, her story adheres to anachronistic tradition, as symbolized by her corset (Furo et al. 2016).

In discussions of Merida's influence as part of the Disney princess collection, however, the importance of her prowess in archery has been largely overlooked, even though promotional material and products generally feature her with her bow and arrows (see for example (Hine et al. 2018a), or Merida products such as t-shirts on Amazon.com). This attribute distinguishes her from other princesses whose identities are not linked to a sport. The controversy in 2013 that ensued when Disney re-formulated Merida as part of her "coronation" as an official Disney princess reveals the salience of her archery accoutrements. The Merida doll was shaped in a more sexualized form than in the film, reflected in the curves of her body and the appearance of wearing makeup. Of note, the feminine transformation also dispensed with her bow and arrows, excising her toxophily and eliminating her "refreshing" tomboy image (Lester 2019, p. 195). Given the importance of archery to Merida's tomboy identity, the role of the sport in how she performs gender (Butler 2004) merits analysis. Merida's shift from hegemonic masculinity epitomized in the archery contest to humility and penitence as she transitions out of childhood does not support her stature as a role model that flouts gender stereotypes. This article argues that her tomboy trajectory ultimately affirms rather than defies traditional gender roles that the film reputedly eschews.

\section{Plot Summary}

A Scottish princess Merida embraces the tomboy model of conduct, preferring archery over princess etiquette. While her mother carps at her, her father is part loveable buffoon, part brave warrior who fought off a mighty enchanted bear, Mor'du, losing one of his legs to the bear in the encounter. When faced with the unwelcome prospect of suitors competing for her hand in marriage, Merida strategically proclaims that the contest will involve archery, a selection based on her skill and love of the sport that her father encouraged from an early age. Merida surprises the crowd attending the competition when she herself enters the contest at the end. The upshot (technically speaking, the last arrow launched) is Merida's dramatic bullseye that split what had seemed to be the winning arrow of one of the suitors, making her the victor. Her mother then chastises her for humiliating the suitors, a breaking point in their relationship. Fed up with her mother's wish to control her and make her more feminine, Merida slashes her mother's tapestry before running off to a witch for a magical remedy to end her powerlessness. After the witch's sorcery unexpectedly turns her mother into a bear, Merida tries to break the spell before her mother becomes a bear permanently. Her only clue to undoing the hex is the witch's riddle, to "mend the bond torn by pride." Merida comes to believe that the "pride" mentioned in the witch's riddle refers to her "selfish" ways; at the same time, her mother recognizes that her daughter should find love on her own schedule. The culminating moment of the film is Merida's tearful apology in which she concedes that the various troubles depicted in the film were all her fault, as she avows publicly that she needs and loves her mother, admissions that reverse the spell, and reunite daughter and mother in human form.

\section{Merida as a Quintessential Tomboy}

Brave was celebrated for its princess that rejected stereotypical femininity. The extent to which Merida instead embraced masculinity is more prominent than in other Disney princesses. After assessing masculine traits like being physically strong, assertive, unemotional, independent, athletic, inspiring fear, giving advice, and taking on the role of leader, Hine et al. (2018b) reported that Merida has more masculine traits (62\%) than the other "mighty maidens": Elsa and Anna at 50\% (from Frozen) and Rapunzel at $44 \%$ (from Tangled). Furthermore, Merida also exhibits a disproportionate number of masculine traits when compared to the princes (her suitors). In fact, Brave has the biggest gap in masculine characteristics when comparing princesses and princes: Merida exhibits $67 \%$ more 
masculine characteristics than the princes (suitors) in Brave followed by the second greatest gap, a 47\% disparity, found in Princess and the Frog comparing Tiana to Prince Naveen.

For example, in the character-defining song Touch the Sky, Merida displays a number of these so-called masculine traits: immediately after awakening, and without grooming her flyaway ginger hair, Merida grabs her bow and arrow, and pushes past dismayed castle staff to hop atop a banister. As she skids across the handrail to speed her descent past bustling servants, she snatches an apple off a tray. Holding this breakfast-on-the-go with her teeth, she then jumps off the banister, flashing her pantalette undergarment. She then takes a shortcut by jumping off the side of the stairs onto a tall floor candelabra below. She bounces off the fixture, toppling it to the floor with a clatter that elicits an alarmed squawk from a chicken in the arms of a nearby scullion. Once outside, she mounts her horse with a running leap and gallops through the castle portcullis into the rugged Scottish Highlands for horseback archery target practice. She then engages in free soloing, ascending a sheer, tall rock face. She is barely fazed when she temporarily loses her grip. To avoid a fatal fall, she clings to the face of the rock with only one hand, as her vigilant horse Angus neighs nervously below. After a quick recovery, she reaches the top of the looming rock where she celebrates her death-defying ascent by drinking from a nearby waterfall.

It could be that this "androgyny" explains why among a sample of 8 to 9 year old children, only $56 \%$ thought Merida was a princess, lower than the other "mighty maidens", who were perceived as a princess: Rapunzel (82\%) and Elsa and Anna (83\%) (Hine et al. 2018a). Without qualitative data to explain these findings, it is unclear why Merida is less likely than her peers to be considered a princess (and if this finding is linked to why she is one of the least popular princesses (Dundes and Streiff 2016)). The way in which she expresses masculinity, however, could play a role in how she is perceived. Despite drawbacks to using the term tomboy, it provides a useful paradigm to assess Merida who closely models the stereotypical embodiment of a fictional tomboy likely to, "chafe at the restrictions of imposed femininity and 'girly-girl' ways [yet who] ultimately succumb[s], at least partially, to that which she has struggled against [as she] begins to value traits and activities associated with 'the feminine'" (Thorne 1993, p. 112-13).

Merida has been dubbed a "tomboy" princess, according to the actress that provides Merida's voice (Ford 2012; O'Hagen 2012), fan sites (e.g., Disney Princess Fandom 2020) as well as countless reviewers (e.g., Buettner 2012; French 2012; Pols 2012), including renowned film critic Roger Ebert who also calls her a "plucky honorary boy" (Ebert 2012). Tomboys are girls that are conspicuously independent and involved in male-associated activities (Thorne 1993). Seen as "one of the guys", they commonly feel a sense of pride about this label, in contrast to boys subject to censure when they display stereotypically feminine traits (Coyle et al. 2016): "Spirited and adventuresome, they like to move freely and to be outdoors ... [and] struggle with those, usually including their mothers, who would tie them down ... [and insist on] 'manners'"' (Thorne 1993, p. 112). Despite widespread agreement that Merida personifies the tomboy trope, the use of the word itself risks perpetuating gender stereotypes in designating certain traits as masculine. In other words, the term tomboy validates the oppositional dichotomies of gender roles (in which certain traits-positive traits-are designated masculine). At the same time, the term also reinforces confined notions of gender (as does the label sissy that is connected to rigid views of masculinity linked to homophobia) (Bray 2015; Coyle et al. 2016). Nevertheless, the concept of a "tomboy" is likely to have sustained resonance as a "cultural slot" (Thorne 1993, p. 120).

Merida's love of outdoor activity, consistent with Thorne's delineation of a tomboy (above), is at odds with her mother's expectations for her deportment. Merida's mother, Queen Elinor, constantly carps at her daughter to instill stereotypical femininity. As a result, Merida identifies with and prefers her father, the source of her untamed ginger curls. The other meanings of "ginger", spirit and resilience, also appertain, especially in contrast to her mother who has neatly coiffed, silky brown locks, exuding the queen's preference for order over spontaneity (Leader 2018). Thus, the symbolism of hair in the film serves as an additional means for Merida to disidentify from her mother and reject stereotypical femininity. Merida's repudiation of femininity is complemented by her love of 
archery, a sport associated with masculinity. In fact, the word "bowman" lacks a female form (like the word "fisherman", another male-dominated sport (Streiff and Dundes 2017b)). The sport remains male-dominated as symbolized by the legendary Robin Hood, even as female participation has risen (to $22 \%$ of all archers), a rate boosted by Brave (Davis 2016) ${ }^{1}$. Nevertheless, most competitive archers are men, with only one well-known woman (Khatuna Lorig) among the top real-life archers (Archery Trade Association 2016; Davis 2016). As a tomboy princess, it is not surprising that Merida appeared holding her bow and arrows in promotional material about Brave, a sign that her archery skills help define her.

Merida's repudiation of femininity is reinforced in a scene that depicts the breaking point in the mother-daughter relationship when Merida unequivocally rejects her mother who is quintessentially feminine in her mannerisms, goals, and personal appearance, traits that are notably oppositional to Merida's tomboy identity:

Merida: I will NEVER be like you! [Merida sticks the tip of her sword into her mother's tapestry]

Queen: NO! Stop that!

Merida: I'd rather DIE than be like you!

[Merida suddenly slashes the tapestry, after which the queen throws Merida's bow into a burning fire]

Merida's rejection of her mother and her mother's femininity lack subtlety as the conflict shows the contrasting symbolism of the tapestry her mother has sewn (feminine behavior) and Merida's bow (a masculine tool complemented by an etching of an eagle, a raptor that is a bird of prey). Although the queen retrieves Merida's bow from the fire after Merida leaves the room, her desire to steer her daughter away from archery is apparent.

\subsection{Tomboyism as Dilatory Tactic on Path to Adulthood}

If femininity is merely delayed for many girls deemed tomboys, then the tomboy narrative could also reflect fears of growing up or "resistance to adulthood itself rather than to adult femininity" (Halberstam 1999, p. 156). However, it is important to note that in Brave, adulthood is equated with marriage, when Merida is pushed to go from child to adult, with no transition. The above-mentioned song Touch the Sky emphasizes her love of avoiding adult responsibility (as well as tomboy-associated sports like unharnessed, high-risk rock climbing). The song's key catch phrase is "chase the wind" (repeated five times), a metaphor for futility (from Ecclesiastes 1:14). Her self-indulgent outdoor pursuits that the song labels as devoid of purpose contrast with the compromises and responsibilities of marriage. In fact, the abrupt graduation from innocent to sexual foisted upon Merida provides insight into how tomboyism is not just (temporary) empowerment, but also helps girls "deflect" the male gaze and insulates them from "coercive romantic positionings" (Renold 2009, p. 236).

The film emphasizes this point when Merida's father mocks her in falsetto: "I don't want to get married. I want to stay single and let my hair flow in the wind as I ride through the glen firing arrows into the sunset." The king links the repudiation of marriage to the useless firing of arrows into the sunset, implying that her archery is not even target practice, let alone hunting or defense. He also references the theme in which Merida's hair is a metaphor for flouting rules governing women's appearance (Leader 2018), another sign of her disregard for the male gaze.

1 The most notable fictional archers across all ages and gender, are listed here in descending order of a study's respondents that mentioned the character as influential in them taking up the sport: Robin Hood (23\%), Katniss Everdeen in The Hunger Games (15\%), Legolas from The Lord of the Rings franchise (14\%), Princess Merida from Brave (12\%), Hawkeye from The Avengers franchise ( $9 \%$ ), and Green Arrow from the Arrow television series (9\%), showing that one third of the most prominent fictional archers are female (Davis 2016). 
Despite that her tomboyism was functional in delaying her transition from childhood innocence to nubile woman ready for matrimony, her eventual acceptance of the femininity modeled by her mother suggests that tomboyism also effectively delayed the responsibilities of growing up. For Merida, maturity seems to entail ending the rebellion against her mother and overlooking how her mother tried to make her traditionally feminine. With the mutiny over, Merida can express stereotypical femininity, displayed when she cries with contrition, publicly declaring that she loves and respects her mother. This emotional epiphany is key to reversing the spell that turned her mother into a bear, with the implication that such a change is laudable as it heralds the imminent and proverbial "happy ending".

[Merida begins to cry and kneels before her mother]. Oh, mom, I'm sorry. This is all my fault.

I did this to you, to us. [She tearfully hugs her mother]. You've always been there for me.

You've never given up on me. I just need you back. I want you back, mommy. I love you.

Thus, in some sense, her insubordination is fruitless because she does not gain independence from her mother. Moreover, her deference to maternal authority and seeing herself as "selfish" is out of step with the appeal of princesses as free, independent actors. The notion of a prince weeping and proclaiming, "I just need you back. I want you back, Mommy," underscores how this conclusion would not qualify as a conventional happy ending for a male hero.

This U-turn away from a feminist script brings the movie to a close, allowing Merida to repair the rift with her mother (suggesting that relationships and not power are paramount for women). To emphasize the disparate binary gender roles, the very last scene shows her rambunctious, mischievous brothers as stowaways on a departing ship, a reminder that "boys will be boys". In contrast, Merida seems to illustrate how women that display masculine traits pay a price. Feminine qualities eventually reform Merida, showing her as an enlightened, contrite daughter that sheds public tears, and proclaims her love for and dependence on her mother. Thus, Merida follows the tomboy trajectory, a path that ends in embracing what she has formerly renounced.

\subsection{Hegemonic Masculinity}

Tomboyism, however, is not just displaying traits deemed masculine, but also may involve the appropriation of "hegemonic masculinity" and the "denigration of normative sexualized femininities" (Renold 2009, pp. 226-27). In Brave, Merida's depiction as a tomboy is unambiguous, a mix of Pixar's typical exaltation of hegemonic masculinity (Wooden and Gillam 2014) laced with elements of the popular Disney Princess archetype. Encouraged by her father, Merida valorizes hegemonic masculinity, a dominant form of masculinity that entails subjugating other males (in human or animal form). Early in the film, we see Merida joining her father in reciting the story of his violent confrontation with the bear, Mor'du. In the incident, Mor'du suddenly appears, whereupon the king rushes at the bear that then violently breaks the king's spear in half. The king immediately draws his sword, as he fearlessly goads the bear, shouting, "Come on, you!" before the screen goes blank. We later learn that the king survives, but loses his leg which has been replaced with a wooden peg leg.

In this scene, set in the castle's grand dining room, the queen sits at the table but pays no attention as the king enthusiastically recapitulates the account of his fight with the bear, as one of Merida's young triplet brothers lip-syncs the oft-recited tale, mimicking his father's words and gestures, including gesticulations with a half-eaten drumstick. The king's "favorite part" of the tale is the violent loss of his leg, the part that Merida interrupts to recount herself, with great gusto. Such entertaining stories and personal anecdotes of a credible "coach" (often a parent), however, encourage violence according to violentization theory: "The coach instructs the novice that he should never try to avoid, appease, ignore, or run from his opponents during dominative encounters, but instead should always physically attack them with the intent to kill or gravely injure them" (Athens 2017, p. 503). Thus, Merida reinforces her father's machismo as central to masculine identity, as she relishes the opportunity to bond with him by taking part in the glory of the violence vicariously, a story that she touts as a "legend": 
King: [Holding a big drumstick with bites taken out]: From nowhere, the biggest bear you've ever seen! Its hide littered with the weapons of fallen warriors. Its face scarred with one dead eye. I threw my sword and ...

Merida: [Interrupts with excitement]: Whoosh! One swipe, his sword shattered, then, chomp! Dad's leg was clean off! Down that monster's throat it went!

King: Aww! That's my favorite part!

Merida: Mor'du has never been seen since. And he's roaming the wild, awaiting his chance for revenge. [Merida makes a rrrahr sound like a bear]

King: Let him return. I'll finish what I gobbled in the first place. [Merida places her bow on the table]

Queen: Merida, a princess does not place her weapons on the table.

Merida: Mom! It's just my bow.

Queen: A princess should not have weaponry in my opinion.

King: Leave her be! Princess or not, learning to fight is essential. ${ }^{2}$

This scene illustrates how her father inculcates in her the masculine values of fighting and facing violence bravely, including his bravado to "finish what [he] gobbled in the first place", that is, a desire to "finish" a fight with an undefeated adversary, no matter the danger. Her mother shows no interest in the violent account, only paying attention enough to interject attempts to instill feminine propriety as she spearheads the effort to find a husband for Merida. In fact, the queen's superior authority and finesse (in all matters) add to the king's need to compensate for his defeat by the bear.

While the legend of Mor'du overtly celebrates hegemonic masculinity, ridicule also supports a hierarchy of male dominance. With a range of forms from satire to sarcasm, this brand of humor makes someone the target or butt of derision, in which the term derision, like ridicule, is based on the Latin word ridiculus or "laughable" from ridere "to laugh". Actors that deride a target (or "butt") are subject to rules based on the gender hierarchy in which humor can be aggressive, as the terms biting or caustic humor suggest. ${ }^{3}$ The social norm in which men joke around to bond (Finney 1994) ultimately helps determine a "pecking order" in which men's "peckers" symbolically determine the hierarchy. Similarly, a "henpecked" husband is humiliated because a hen, that is, a female, usurps the active male pecking role of the cock. Ridicule in which men are the butt often entails feminizing them, conflating femininity with deviations from heteronormativity. Feminizing humor not only bolsters masculinity based on homophobia, but also reflects misogyny (Connell 1995).

When Merida ridicules the suitors, her mother disapproves. The queen's reaction paints her as a killjoy while her father is the "fun", relatable parent. This scene in which the suitors are ridiculed reinforces the stereotype that women who fail to laugh at jokes are uptight and humorless (Hitchens 2007). ${ }^{4}$ In Merida's case, when she questions her suitors' masculinity, she bonds with her father. Similarly, women working in male-dominated hierarchies may engage in homophobic mockery of a male colleague to gain the approbation of men in power in a way that can be trivialized as just a joke (Plester 2015). Likewise, the phrase, "just kidding" can rarely be taken literally but rather offers a

2 Merida placing her bow on the table mirrors her father's same faux pas earlier (that elicits the same criticism), an echo of the "trident and fork" theme of Disney's Little Mermaid (Dundes and Dundes 2000).

3 During a joke, there may be "jabs" (short punches) prior to the "punch" line in which the "butt" is targeted that may cause the audience to crack up or be in stitches, from Old English stice, meaning "a puncture, stabbing pain" (as in having a stitch in one's side when running). To be the late-night punch line means to be the butt of a joke on a talk show, an insult meant to connote powerlessness.

4 The 1970s popular joke series about screwing in lightbulbs includes an example relevant to this discussion: "How many feminists does it take to screw in a lightbulb? That's not funny" (Dundes 1981). The punchline reveals that women who seek equality (and more equal power in society) lack a sense of humor; they are wet blankets unwilling to be a receptive audience that validates the status quo of men. 
socially acceptable way to ridicule a target (McCann et al. 2010). In the archery contest, Merida and her father make all three suitors the butt of ridicule in a way that sanctions hegemonic masculinity as parent-child camaraderie and bolsters Merida's tomboyism.

\section{The Emasculation of Suitors in the Archery Contest}

The archery contest draws a rabble of boisterous onlookers from the surrounding Highland communities, attracting those eager to see who will win Merida's hand in marriage. The air is filled with anticipation, eliciting murmurs, cheers and claps from the crowd as they await the ensuing competition. After the crowd quiets, the first suitor, a large, gentle and awkward Young MacGuffin, shoots his arrow, which lands very wide of the mark (on the edge of the target). The crowd reacts with a mixture of surprise, sympathy and scorn, while Merida jokes to her father, "I bet he wishes he was tossing cabers." After both father and daughter laugh derisively, Queen Elinor slaps Fergus' arm to convey her disapproval to encourage them to behave with decorum, presumably because to "toss the caber" means male masturbation (Hush 2004; Tossing 2020). Merida's ridicule implies that the suitor's sub-par masculinity makes him better off resorting to self-gratification. This ribald exchange that excludes the queen allows Merida and her father to bond over a type of humor that supports hegemonic masculinity.

The next suitor, Young Macintosh, revels in the spotlight. He turns to the crowd before abruptly and dramatically turning back to immediately release his arrow. After narrowly missing the center of the target, he throws a full-fledged tantrum, lifting his chin to emit a distressed howl. He then uses his bow to thrash the ground. Merida, amused, wryly says to her father, "Oh, that's attractive." After Young Macintosh hurls his bow into the crowd (where someone catches it), Merida sarcastically adds, "Good arm!". Her father joins her in mocking the suitor while flicking his own hair with effeminate panache and saying, "And such lovely flowing locks". Although Queen Elinor rebukes him for snickering at his own joke, he feigns innocence of wrongdoing.

When the third and final suitor, Wee Dingwall, prepares to shoot, he appears to be using a bow and arrow for the first time, inadvertently twirling as he struggles to pull an arrow from his quiver. He then wrestles with the bow as he tries to properly position the arrow, watching it veer out of position, as if he is helpless to control its movement. Prior to his subsequent lucky bullseye, Merida mockingly conveys pity and with clear disdain, says, "Oh, wee lamb." A lamb is a young sheep, with a metaphorical meaning of someone weak that is too easily influenced by others. ${ }^{5}$ Even though "wee" is part of his moniker, "wee" emphasizes weakness when combined with being subject to others" dominion. While he struggles to gain control of the bow (let alone aim or look at the target), he is startled into releasing the arrow when the king slaps his forehead in frustration and bellows, "Oh come on! Shoot, boy!" Wee Dingwall is stunned but pleased with his seemingly lucky winning placement of the arrow into the center of the target.

These various remarks, from "That's attractive" to "Wee lamb", may seem to be innocuous humor. Yet the etymologies of snide and sarcastic, that characterize Merida's insults, belie their harmlessness: "sarcasm" connotes its etymology of ripping off the flesh (Greek: derived from "sarkazein": "to tear flesh like a dog") (Sarcasm 2020), while "snide" is likely linked etymologically to a dialectal variant of snithe ("sharp, cutting") (Snide 2020). The aggression underlying these barbs is more acceptable among men, a phenomenon that makes women stand-up comedians struggle for acceptance since certain types of humor violate gender stereotypes (Kim 2019). In the case of Merida's admittedly polysemic mockery of the suitors, it is consistent with dominant masculinity that complements her tomboy profile.

5 In the well-known nursery rhyme and song, Mary had a Little Lamb (Roud Folk Song Index 7622), a male lamb follows Mary around and looks to her for protection, emphasizing lambs' association with meekness and vulnerability (which also explains the role of Little Bo Peep as shepherd). 
Most revealing, however, is her participation as an unexpected final contestant. She shoots three bullseyes, with the final shot, the upshot, superseding Wee Dingwall's accidental bullseye, in a scene laden with symbolism. She penetrates his arrow as hers continues on to pierce the entire target through and through. Merida's bullseye is one of the most dramatic moments of the film, with its importance emphasized by its enactment in slow motion, both creating suspense and allowing the audience to savor her victory over the suitors. Although Merida's defeat of the men is patently triumphant, its symbolism carries latent meaning that likely was not consciously intended beyond how her feat elicits her mother's consternation:

\section{Queen: "You just embarrassed them! You embarrassed ME!"}

This "embarrassment", especially the final bullseye, was a literal and figurative "game changer". Yet why the bullseye precipitated the final breakdown in the relationship between mother and daughter is open to interpretation. One explanation proposed in this paper is the latent hegemonic symbolism of a bullseye. A bullseye is the most prized position on the butt (target), with the semiotics of the term related to bull symbolism. In bullfights, bulls are incited to fight hard to enhance the masculinity of those that impale (and feminize) them, explaining why victors may also symbolically castrate the bull (Dundes 1997; Kalof 2014). In other words, the impalement of a bull overtly confers virility through its feminization. In particular, a bullseye on a target could help underscore the latent allure of archery outside of hunting and battle, which are male-dominated activities in which proving masculinity is more overt. Furthermore, because archery is not a contact sport in which an archer dominates another human or animal physically, the bullseye can substitute as a means to symbolically prove masculinity by feminizing a male opponent.

The deeper, latent meaning of how a bullseye feminizes competitors relates to both the semiotics of arrows and the word "bullseye" itself. In the early days of archery, the word for arrow, prickshaft (Hall 2018, p. 55; Prickshaft 2020), reflected phallic symbolism (in both syllables) as does the cock feather (for the aerodynamic stabilization of arrows). A bullseye thus involves a phallic arrow (prickshaft) that hits the target, also called a "butt" (Butt 2020; Roberts and Wood 1801). There is a possible connection between the butt as target and a bullseye as the center of the target, making the bullseye the center of the butt. However, the word "eye" should be interpreted as symbolic and reflective of upward displacement. ${ }^{6}$ Because no animals have a single, central eye, the center of the target or butt, that is the "bullseye," could be a metaphorical anus that, when penetrated, symbolizes male dominance. ${ }^{7}$ The link between an eye and an anus is supported by the term "anal wink", which has been used to describe the reflex response of the sphincter muscle when stimulated (Cheit 2014, pp. 62, 121). In addition, the notion of an anus as an eye is represented more overtly in an obscure Japanese yōkai phantom, shiri-me (尻目), literally meaning “buttocks eye” (Bane 2016; Yoshida 1995).

Further support of the notion that a bullseye symbolizes anal penetration as feminizing is the expression, "To wear a bullseye on one's back" (never on one's front, where eyes are located). This interpretation relates to males' fear of being feminized by a male rape (an attack from the rear). Likewise, the sports symbolism of, "Couldn't hit a bull in the ass with a bass fiddle" references anal penetration of a bull as a measure of manhood. Concern about anal penetration is also apparent in the general term, "to have someone's back" or in military parlance, IGYS "I've got your six" (with 6 as a reference to its location on a clock), as well as to "CYA" (cover your ass) (Dundes 1978). ${ }^{8}$ These

6 Maidenhead as a term for virginity exemplifies upward displacement (Dundes 2002).

7 Wee Dingwall's lucky bullseye prompts his father to dance a victory jig to taunt the fathers of the other suitors, topped off by his father lifting his kilt to reveal his own unscathed "butt" to them, declaring, "That's my boy" (who penetrated the butt).

8 The game Pin the Tail on the Donkey as well as the hapless donkey Eeyore in Winnie the Pooh stories reflect this pattern (as the Latin word penis also means tail). After continuously losing his tail adorned with a feminizing pink ribbon, gloomy Eeyore must have his tail nailed back in. For both donkeys, the "ass of the ass" is impaled or pinned (with "pinned" being a term of symbolic feminization in wrestling, a male sport). 
expressions point to how the feminization of men, or rather its prevention, is part of the daily lexicon that unconsciously reinforces hegemonic dominance similar to Merida's showstopping bullseye.

While there is no incontrovertible proof that a bullseye symbolizes anal penetration as a form of hegemonic superiority in archery, anal penetration is a more blatant element of cornhole competitions as well as in a variant of cornhole called bean-bag bullseye (Farrell 1974). Cornhole terminology leaves little to the imagination in the underlying meaning of a "bean-bag bullseye", an example relevant to decoding the same pattern in the archery scene in Brave. First, the noun cornhole itself is slang for anus and as a verb denotes enacting the penetrative role in anal intercourse (Allen 2000; Green 2005). The word corn in this context does not refer to the plant, but rather thickened skin related to cornu or an animal's horn (Corn 2020), a phallic symbol (Hall 2018) as suggested by the word "horny" and the fact that animal horns are marketed as aphrodisiacs.

The game itself has many terms that support a win as symbolic of a male feminizing a male opponent. The phallic element of a male aggressor is evident in the term woody that refers to any cornhole bag that has been pitched and remains on the cornhole board playing surface at the conclusion of the frame; a Slick Woody or a Slick Willie is "a bag [that] slides directly into the hole" (Cornholemart 2019). The hole, sometimes called a "dadhole" is thus coded as male and has manifest anal properties revealed in the terms dingleberry, slang for a "bag hanging on the edge of the hole, ready to drop in" (Cornholemart 2019) and hemorrhoids, when bags on the board block the hole, in line with other cornhole slang like "glory holes" and "rim jobs". Furthermore, feminization is to be avoided as suggested by the slang for weak shots: a Sally, Suzy or a Mary (Cornholemart 2019). These are insults that likely lack the same sting for female players since the stakes are generally greatest in male-against-male competition.

Despite adopting hegemonic masculinity consistent with the tomboy paradigm, and like the underlying sexist logic of a "Sally, Suzy or Mary" described above in cornhole, Merida must contend with stereotypes of femininity that are at odds with her feminizing her suitors. In other words, as a woman competing against males, she internalizes male hegemony yet in the long term, she still runs afoul of wariness about women competing against men (a general phenomenon noted by scholars: e.g., (Bryson 1987; Konieczny 2020)). It matters that her mother's consternation is in response to her victory. It also matters that this violation of gender norms triggers the events that turn her mother into a bear. What becomes important is not her mastery of archery that is exceptional for women and men alike, but ultimately that she goes too far on the tomboy trajectory, as encompassed by the latent meaning of her momentous bullseye.

\section{Return to a Feminine Script}

Shortly after Merida's humiliation of her suitors, her focus turns to her relationship with her mother who has become a bear. Introspection supersedes archery as Merida struggles to interpret the witch's riddle that holds the key to reversing the spell: "mending the bond torn by pride". Merida believes she must give in to tradition and deny her own wishes. Just as she is about to announce that she will do what is "right" and move forward on the path to matrimony, her mother pantomimes that she instead should choose her own path. As a result, Merida abruptly changes what she was about to publicly proclaim. Thus, first she decides to conform to matrimonial convention because she has "been selfish" and needs to "mend" bonds, a nurturing, feminine role that complements the altruism expected of women. However, she then pivots after gaining her mother's permission to follow her heart and find love in her own time:

"I've been selfish. I tore a great rift in our kingdom. There's no one to blame but me. And I know now that I need to amend my mistake and mend our bond. And so, there is the matter of my betrothal. I decided to do what's right, and ... [looking around the room, she sees her mother in the background motioning her to change course] And ... and break ... tradition. [She then takes her cues from her mother who is miming what she should say]. My mother, the queen, feels ... uh, in her heart, that I ... that we be free to ... write our own story. To 
follow our hearts and find love in our time. The queen and I put the decision to you, my lords. Might our young people decide for themselves who they will love?". [italics added]

The above passage shows that even after asserting that she and her mother believe that she should be free "to write her own story", she turns the question-and the agency-to the men of the clans, to whom she "put[s] the decision". In essence, she chooses humility over forthrightness, following a script in which women wield power only indirectly, democratically, and with affective sensibility as she defers to the men who are the real powerbrokers (even when they behave like buffoons). This pivotal moment when Merida addresses the crowd negates her tomboy gender nonconformity in which girls initially aspire to "the greater freedoms and mobilities enjoyed by boys" (Halberstam 1999, p. 155). In addition, in accordance with the tomboy trajectory, Merida's empowerment is illusory as her story is not modern, but rather remarkably in line with the longstanding final stage of the paradigm in which, "tomboy instincts of millions of girls are remodeled into compliant forms of femininity" (Halberstam 1999, p. 156). Girls' adoption of stereotypically masculine traits as tomboys is more acceptable and less threatening when they are young and less powerful, as suggested by the word "boy" in tomboy. This reinforcement of how adult women are supposed to perform gender supports a constrictive gender binary (Butler 2004). As a result, the touted mother-daughter reconciliation in Brave resembles a "prodigal daughter" tale in which a deviant performance of gender upsets familial harmony and must be rectified. The happy ending hinges on an epiphany about leaving hegemonic masculinity to men and embracing femininity, a disappointing outcome for a princess marketed as brave.

\section{Conclusions}

Merida's archetypal tomboy trajectory ends in her succumbing to what she had initially rejected. Her spirited independence seems to have been doomed when she followed the script of hegemonic masculinity, accentuated by her emasculating bullseye. When her tomboyism fades, she confirms the need for parental guidance, breaking the illusion of autonomy. In an anachronistic display of binarism, she shifts from hegemonic masculinity to guilt, contrition and dependence that jibe with the feminine gender stereotype. This leaves open the question of whether her masculine traits were strategic (to avoid the shift into adulthood and its duties), or a desire to claim masculine power and authority, or an expression of her innate sense of self that falls outside of the limiting gender binary, or some combination of the three. In any case, the tomboy trajectory in Brave involves a girl following the masculine script, only up until the time that she stops rebelling against her femininity. It is a conception of girls as temporarily masculine until they reach maturity which in Merida's case occurred when she gained clarity about the witch's riddle, in which her "pride" was deemed to be hubris and the adoption of masculine traits turned into a liability. Rather than forging her own path, she becomes reconciled to adopting the dictates of more feminine characteristics. Princesses, however, should not be constrained by either the rejection of or adherence to gender roles. Instead, as role models for their audience, their personal growth should be free of the confines of gender scripts.

Funding: This research received no external funding.

Acknowledgments: The author acknowledges Madeline Streiff Buitelaar for discussions of ideas central to this paper.

Conflicts of Interest: The author declares no conflict of interest.

\section{References}

Allen, Gary. 2000. Desire on the Menu. Journal for the Study of Food and Society 4: 29-38. [CrossRef]

Archery Trade Association. 2016. Available online: https://archerytrade.org/grow-archery/ (accessed on 1 May 2020).

Athens, Lonnie. 2017. Applying violentization: From theory to praxis. Victims \& Offenders 12: 497-522.

Bane, Theresa. 2016. Encyclopedia of Beasts and Monsters in Myth, Legend and Folklore. Jefferson: McFarland and Company, Inc. 
Bray, Danielle Bienvenue. 2015. Sissy Boy Mothering: Male child mother figures in middle-grade fantasy literature. Children's Literature in Education 46: 160-74. [CrossRef]

Bryson, Lois. 1987. Sport and the maintenance of masculine hegemony. Women's Studies International Forum 10: 349-60. [CrossRef]

Buettner, Justin. 2012. Film Review: Brave. Available online: https://www.stylemg.com/2012/06/23/37928/filmreview-brave (accessed on 1 May 2020).

Butler, Judith. 2004. Undoing Gender. London: Psychology Press.

Butt. 2020. Available online: http://www.dictionary.com/browse/butt (accessed on 25 April 2020).

Cheit, Ross E. 2014. The Witch-Hunt Narrative: Politics, Psychology, and the Sexual Abuse of Children. New York: Oxford University Press.

Connell, Raewyn W. 1995. Masculinities. Cambridge: Polity Press.

Corn. 2020. Available online: https://www.etymonline.com/word/corn (accessed on 25 April 2020).

Cornholemart. 2019. Ultimate Cornhole Terminology. Available online: http://cornholemart.com/cornhole-terms/ (accessed on 1 May 2020).

Coyle, Emily F., Megan Fulcher, and Darinka Trübutschek. 2016. Sissies, Mama's Boys, and Tomboys: Is Children's Gender Nonconformity More Acceptable When Nonconforming Traits Are Positive? Archives of Sexual Behavior 45: 1827-38. [CrossRef]

Davis, Geena. 2016. Hitting the Bullseye: Reel Girl Archers Inspire Real Girl Archers. SeeJane.Org. Available online: https://seejane.org/wp-content/uploads/hitting-the-bullseye-reel-girl-archers-inspire-real-girl-archersfull.pdf (accessed on 30 April 2020).

Disney Princess Fandom. 2020. Available online: https://disneyprincess.fandom.com/wiki/Merida (accessed on 30 April 2020).

Dundes, Alan. 1978. Into the endzone for a touchdown: A psychoanalytic consideration of American football. Western Folklore 37: 75-88. [CrossRef]

Dundes, Alan. 1981. Many Hands Make Light Work or Caught in the Act of Screwing in Light Bulbs. Western Folklore 40: 261-66. [CrossRef]

Dundes, Alan. 1997. Traditional Male Combat: From Game to War. In From Game to War and Other Psychoanalytic Essays on Folklore. Lexington: University Press of Kentucky, pp. 25-45.

Dundes, Alan. 2002. Bloody Mary in the Mirror: A Ritual Reflection of Pre-Pubescent Anxiety. In Bloody Mary in the Mirror: Essays in Psychoanalytic Folkloristics. Edited by Alan Dundes. Jackson: University Press of Mississippi, pp. 76-94.

Dundes, Lauren, and Alan Dundes. 2000. The Trident and the Fork: Disney's 'The Little Mermaid' as a Male Construction of an Electral Fantasy. Psychoanalytic Studies 2: 117-30. [CrossRef]

Dundes, Lauren, and Madeline Streiff. 2016. Reel Royal Diversity? The Glass Ceiling in Disney's Mulan and Princess and the Frog. Societies 6: 35. [CrossRef]

Dundes, Lauren, Madeline Streiff, and Zachary Streiff. 2018. Storm Power, an Icy Tower and Elsa's Bower: The Winds of Change in Disney's Frozen. Social Sciences 7: 86. [CrossRef]

Dundes, Lauren, Madeline Streiff Buitelaar, and Zachary Streiff. 2019. Bad Witches: Gender and the Downfall of Elizabeth Holmes of Theranos and Disney's Maleficent. Social Sciences 8: 175. [CrossRef]

Ebert, Roger. 2012. Roger Ebert.com. The Story of a Plucky Honorary Boy. Available online: https://www. rogerebert.com/reviews/brave-2012 (accessed on 6 May 2020).

England, Dawn Elizabeth, Lara Descartes, and Melissa A. Collier-Meek. 2011. Gender role portrayal and the Disney princesses. Sex Roles 64: 555-67. [CrossRef]

Farrell, Carolyn. 1974. Four projects you'll find fun and handy. Popular Mechanics, September. 138.

Finney, Gail. 1994. Unity in Difference? An Introduction. In Look Who's Laughing: Gender and Comedy (Introduction). Edited by Gail Finney. Amsterdam: Gordon and Breach, pp. 1-13.

Ford, Rebecca. 2012. The "Boardwalk Empire” Actress, Who Tells THR She Didn't Have a lot of Familiarity with Disney Princesses, Voices Pixar's First Heroine in the Upcoming Disney Film. The Hollywood Reporter. June 20. Available online: https://www.hollywoodreporter.com/news/brave-kelly-macdonald-merida-pixar-340206 (accessed on 6 May 2020).

French, Phillip. 2012. Brave-Review. Available online: https://www.theguardian.com/film/2012/aug/19/bravefilm-review-kelly-macdonald (accessed on 6 May 2020). 
Furo, Annette, Nichole E. Grant, Pamela Roger, and Kelsey Catherine Schmitz. 2016. The Corseted Curriculum: Four Feminist Readings of a Strong Disney Princess. In Disney, Culture, and Curriculum: Studies in Curriculum Theory Series. Edited by Jennifer A. Sandlin and Julie C. Garlen. New York: Routledge.

Giroux, Henry A. 1999. Children's Culture and Disney's Animated Films. In The Mouse that Roared: Disney and the End of Innocence. Edited by Henry A. Giroux. Lanham: Rowman \& Littlefield Publishers, pp. 83-121.

Green, Jonathon. 2005. Cassell's Dictionary of Slang. London: Sterling Publishing Company, Inc.

Halberstam, Judith. 1999. Oh Bondage up Yours: Female Masculinity and the Tomboy. In Sissies and Tomboys: Gender Nonconformity and Homosexual Childhood. Edited by Matthew Rottnek. New York: NYU Press, pp. 153-79.

Hall, James. 2018. Illustrated Dictionary of Symbols in Eastern and Western Art. New York: Routledge.

Hine, Benjamin, Katarina Ivanovic, and Dawn England. 2018a. From the sleeping princess to the world-saving daughter of the chief: Examining young children's perceptions of 'old' versus 'new' Disney princess characters. Social Sciences 7: 161. [CrossRef]

Hine, Benjamin, Dawn England, Katie Lopreore, Elizabeth Skora Horgan, and Lisa Hartwell. 2018b. The Rise of the Androgynous Princess: Examining Representations of Gender in Prince and Princess Characters of Disney Movies Released 2009-2016. Social Sciences 7: 245. [CrossRef]

Hitchens, Christopher. 2007. Why Women Aren't Funny. Vanity Fair. Available online: https://www.vanityfair. com/culture/2007/01/hitchens200701 (accessed on 25 April 2020).

Hush, Margot. 2004. Autoerotic Behaviors and Patterns. In The Continuum Complete International Encyclopedia of Sexuality. Edited by Robert T. Francoeur and Raymond J. Noonan. London: A\&C Black, p. 1099.

Kalof, Linda. 2014. Animal blood sport: A ritual display of masculinity and sexual virility. Sociology of Sport Journal 31: 438-54. [CrossRef]

Kapurch, Katie. 2016. Something Else Besides a Daughter? Maternal Melodrama Meets Postfeminist Girlhood in Tangled and Brave. The Lion and the Unicorn 40: 39-61. [CrossRef]

Kim, Jean. 2019. Women and Their Struggle to Be Considered Funny as Told through the Study of Female Standup Comics. New York: Master of Arts, Liberal Studies Program, City University of New York (CUNY), Available online: https://academicworks.cuny.edu/cgi/viewcontent.cgi?article=4184\&context=gc_etds (accessed on 15 April 2020).

Konieczny, Julia. 2020. There's Nothing Worse than Losing to a Girl: An Analysis of Sex Segregation in American Youth Sports. Indiana Journal of Law and Social Equality 8: 70-88.

Leader, Caroline Ferris. 2018. Magical manes and untamable tresses: (en)coding computer-animated hair for the post-feminist Disney Princess. Feminist Media Studies 18: 1086-1101. [CrossRef]

Lester, Catherine. 2019. Frozen Hearts and Fixer Uppers: Villainy, Gender, and Female Companionship in Disney's Frozen. In Discussing Disney. Edited by Amy Davis. Bloomington: John Libbey Publishing, pp. 193-216.

Manwell, Elizabeth A. 2016. Girl in Bears' Clothing in Greek Myth and Disney/Pixar's Brave. In Classical Traditions in Modern Fantasy. Edited by Brett M. Rogers and Benjamin Eldon Stevens. New York: Oxford University Press, pp. 250-68.

McCann, Pol Dominic, David Plummer, and Victor Minichiello. 2010. Being the butt of the joke: Homophobic humour, male identity, and its connection to emotional and physical violence for men. Health Sociology Review 19: 505-21. [CrossRef]

O'Hagen, Sean. 2012. Kelly Macdonald: I'm So Not a Celebrity. The Guardian. January 14. Available online: https: //www.theguardian.com/tv-and-radio/2012/jan/15/kelly-macdonald-boardwalk-empire-interview (accessed on 2 May 2020).

Pixar.com. 2020. Available online: https://www.pixar.com/feature-films/brave (accessed on 15 April 2020).

Plester, Barbara. 2015. 'Take it like a man!': Performing hegemonic masculinity through organizational humour. Ephemera 15: 537. Available online: http://www.ephemerajournal.org/contribution/\%E2\%80\%98take-it-man \% E2\%80\%99-performing-hegemonic-masculinity-through-organizational-humour (accessed on 5 April 2020).

Pols, Mary. 2012. Why Pixar's Brave is a Failure of Female Empowerment. Time. June 22. Available online: https://ideas.time.com/2012/06/22/why-pixars-brave-isa-failure-of-female-empowerment/ (accessed on 3 May 2020).

Prickshaft. 2020. Available online: https://www.thefreedictionary.com/Prickshaft (accessed on 3 May 2020).

Reilly, Cole. 2016. An Encouraging Evolution Among the Disney Princesses? A Critical Feminist Analysis. Counterpoints 477: 51-63. 
Renold, Emma. 2009. Tomboys and "Female Masculinity": (Dis)Embodying Hegemonic Masculinity, Queering Gender Identities and Relations. In The Problem with Boys' Education Beyond the Backlash. Edited by Wayne Martino, Michael D. Kehler and Marcus B. Weaver-Hightower. New York: Routledge, pp. $224-41$.

Roberts, Thomas, and William Wood. 1801. The English Bowman or Tracts on Archery: To Which Is Added the Second Part of the Bowman's Glory. London: C. Roworth, Hudson's Court, Strand, ISBN-13: 978-1145145917.

Sarcasm. 2020. Available online: https://www.merriam-webster.com/dictionary/sarcasm (accessed on 5 May 2020). Snide. 2020. Available online: https://en.wiktionary.org/wiki/snide (accessed on 5 May 2020).

Streiff, Madeline, and Lauren Dundes. 2017a. Frozen in Time: How Disney Gender-Stereotypes Its Most Powerful Princess. Social Sciences 6: 38. [CrossRef]

Streiff, Madeline, and Lauren Dundes. 2017b. From Shapeshifter to Lava Monster: Gender Stereotypes in Disney's Moana. Social Sciences 6: 91. [CrossRef]

Swartz, Jon. 2020. Disney+ may be the only plus for Disney as coronavirus slams other businesses. Market Watch. April 20. Available online: https://www.marketwatch.com/story/disney-in-the-age-of-covid-19-for-nowdisney-may-be-the-only-plus-2020-04-07 (accessed on 5 May 2020).

Tatar, Maria. 2020. The Fairest of Them All: Snow White and 21 Tales of Mothers and Daughters. Cambridge: Harvard University Press.

Thorne, Barrie. 1993. Gender Play: Girls and Boys in School. Buckingham: Open University Press.

Tossing. 2020. Available online: http://www.sex-lexis.com/-dictionary/tossing+the+caber or https://www.definitionof.com/tossing+the+caber (accessed on 5 May 2020).

Towbin, Mia Adessa, Shelley A. Haddock, Toni Schindler Zimmerman, Lori K. Lund, and Litsa Renee Tanner. 2004. Images of gender, race, age, and sexual orientation in Disney feature-length animated films. Journal of Feminist Family Therapy 15: 19-44. [CrossRef]

Whelan, Bridget. 2012. Power to the princess: Disney and the creation of the 20th century princess narrative. Interdisciplinary Humanities 29: 21-34.

Wooden, Shannon R., and Ken Gillam. 2014. Pixar's Boy Stories: Masculinity in a Postmodern Age. Lanham: Rowman \& Littlefield.

Yoshida, Sanroku. 1995. The Burning Tree: The Spatialized World of Kenzaburō Ōe. World Literature Today 69: 10-16. [CrossRef]

Zipes, Jack. 2015. Beyond Disney in the 21st Century: Changing Aspects of American Fairy-Tale Films. In Fairy-Tale Films Beyond Disney: International Perspectives. Edited by Jack Zipes, Pauline Greenhill and Kendra Magnus-Johnston. New York: Routledge, pp. 278-94.

(C) 2020 by the author. Licensee MDPI, Basel, Switzerland. This article is an open access article distributed under the terms and conditions of the Creative Commons Attribution (CC BY) license (http://creativecommons.org/licenses/by/4.0/). 